Távol-keleti Tanulmányok 2016/1: 93-110.

DOI: $10.38144 /$ TKT.2016.1.5

Simonkay Zsuzsanna

\title{
A minhei mongvorok temetési szokásai ${ }^{1}$
}

\section{Bevezetés: a mongvorok}

Tanulmányomban egy olyan, Kína Qinghai 青海 és Gansu 甘肃 tartományaiban élő, mongol nyelvú népcsoport temetési szokásait mutatom be, mellyel a hazai tudományos életben még nemigen foglalkoztak. Éppen ezért egy rövid bevezetőben tárgyalom a mongvorok földrajzi elhelyezkedését, valamint bepillantást nyújtok a velük kapcsolatos tudományos irodalom történetébe, s csak ezután térek rá cikkem konkrétabb témájára. A bibliográfiában az olvasó egy részletes - ám természetesen nem teljes - szakirodalmi listát talál a mongvorokkal kapcsolatos korai és modern múvekről.

A mongvorok a 2010-es népszámlálás szerinti 289565 fős lélekszámukkal szinte elvesznek a kínai kisebbségek között. ${ }^{2}$ Bár a kínaiak egységesen tunak 土, a nyugati tudósok pedig mongvornak nevezik óket, nem beszélhetünk minden tekintetben egységes népről. Egyrészt a kínai nyilvántartásban tuként regisztrált közösségek nem minden esetben tartják magukat tunak, azaz mongvornak. Másrészról pedig a Qinghai-Gansu határvidéken több, kisebb-nagyobb, egymástól elszigetelt, és ennek köszönhetôen mind nyelvileg, mind kulturálisan meglehetôsen eltérő közösség alkotja a mongvor etnikumot. Ezek közül két nagyobb csoportot érdemes megkülönböztetni. 1. Minhei mongvorok, akik Minhe Hui és Mongvor autonóm megye (Minhe Huizu Tuzu zizhixian 民和回族土族自治县) déli részén, az ún. Sanchuan 三川 régióban élnek mintegy 30 000-en. Önelnevezésük chaghan monguor, azaz „fehér mongol”. 2. Huzhui mongvorok, Huzhu Mongvor autonóm megye

1 A cikk megírásához a 2010-ben az ELTE Belső-ázsiai Tanszékén írt MA szakdolgozatom (Simonkay 2010; témavezetô: Sárközi Alice; bíráló: Birtalan Ágnes) egy rövid alfejezetét vettem alapul, s azt egészítettem ki a legújabb kutatási eredményekkel. Köszönet Balogh Mátyásnak a kínai szavak ellenőrzéséért és a cikkel kapcsolatos kritikai megjegyzéseiért.

2 Roche - Stuart 2015: 5. 
(Huzhu Tuzu zizhixian 互助土族自治县) és az azzal nyugatról szomszédos Datong Hui és Mongvor autonóm megye (Datong Huizu Tuzu zizhixian 大通回族土族 自治县) mongvor lakói. A huzhui mongvorok autonímája monghul, ezért a nyugati szakirodalomban gyakran ezen a néven szerepelnek. Ezen kívül sok mongvor/monghul él még elszórtan Qinghai tartomány keleti, illetve Gansu nyugati felében. Ilyen például a néhány ezer főt számláló dordo közösség, akik a Huangnan Tibeti autonóm prefektúra (Huangnan Zangzu zizhizhou 黄南藏族自治州) központi megyéjének, Rebgongnak (kínaiul Tongren 同任) néhány falvát lakják. A kínai nyilvántartás szerint ők is $t u \mathrm{k}$, ôk maguk azonban szívesebben azonosulnak a környező tibetiekkel, annak ellenére, hogy otthonaikban sokuk még mindig egy, a mongvorral rokon nyelvváltozatot, a dorkét beszéli. ${ }^{3}$

Tudomásom szerint a mongvorokkal bővebben a magyar kutatók közül egyedül Róna-Tas András foglalkozott, aki nyelvészeti témájú múvében elemzi a mongvor nyelv történetét, jellegzetességeit, és bemutatja lehetséges etimológiai kapcsolatait. ${ }^{4}$ Rajta kívül még Kara György írt egy cikket e témában, központba helyezve a szókincs eredetét. ${ }^{5}$ A nemzetközi kutatásban is meglehetôsen elhanyagolták e népcsoportot. Bár a 19. század második felében már eljutott a térségbe az orosz Nyikolaj Mihajlovics Przsevalszkij kapitány (akiről a Przewalski-ló, azaz az ázsiai vadló - mongolul taki - a nevét kapta), majd Grigorij Nikolaveics Potanin, az első róluk szóló részletes híradások csak a 20. század elején készülttek. A belga Scheut-misszió négy misszionáriusa, Albrecht de Smedt (fóként nyelvészet), Antoine Mostaert (fóként nyelvészet), Louis M. J. Schram (főként néprajz, antropológia és történelem) és Dominik Schröder (fóként néprajz és folklór) írt a mongvor nyelvről, történelemről és néprajzról mélyrehatóan. ${ }^{6}$ Az 1950-es évektôl kezdve Buljas Hojcsievna Todaeva foglalkozott a mongvorok nyelvével, ${ }^{7}$

\footnotetext{
Lásd Roche - Lcag Mo Tshe Ring 2013.

Róna-Tas 1966, valamint ugyanennek az újragondolt kiadása: Róna-Tas 2014.

Kara 1985.

6 Potanin 1893, De Smedt - Mostaert 1929-1931, De Smedt - Mostaert 1933, De Smedt Mostaert 1945, Mostaert 1931, Schram 1932, Schram 1954a, Schram 1954b, Schram 1961, Schröder 1952-1953, Schröder 1959, Schröder 1964, Schröder 1970.

7 Todaeva 1973.
} 
majd 1990-tôl egyre több kínai, illetve Kínában élő nyugati kutató kezdett vizsgálódásokat e népcsoport körében. 2006-ban Kevin Stuart szerkesztésében újra kiadták Schram fó múvét, melyet Owen Lattimore bevezetője mellett hat modern tanulmánnyal is gazdagítottak. ${ }^{8} \mathrm{E}$ fejezetekben részletesen tárgyalják a mongvorok történetét, nyelvük sajátosságait, valamint néprajzukat, értékelve Schram eredményeit a modern kutatások tükrében. Manapság már egyre több tudós helyezte érdeklődése középpontjába a térséget, amit jól mutat, hogy az Asian Highlands Perspectives 2015-ben megjelent száma teljes egészében a mongvorokkal foglalkozik. ${ }^{9}$

\section{A „természetes” módon elhunytak temetése}

Mint a legtöbb mongol népcsoport, a minhei mongvorok is más-más módon temetik el a „természetes” és a „nem természetes” módon elhunytakat. ${ }^{10}$ Míg az elóbbi kategóriába azok az emberek tartoznak, akik idős korukban haltak meg úgy, hogy volt házastársuk és gyermekük is, ,nem természetesnek” tartják, ha valaki fiatal korában, gyermektelenül vagy valami különleges körülmény miatt (ilyen például egy baleset, szülés stb.) hal meg. Cikkem két fó fejezetében a természetes és nem természetes módon elhunyt emberek temetésének szokásait mutatom be Kevin Stuart és Hu Jun Death and Funerals among the Minhe Tu (Monguor) címú és Louis M. J. Schram The Monguors of the Kansu-Tibetan Frontier címú múve alapján. Mivel a szerző́k csak a temetések leírására szorítkoznak, és nem értelmezik, magyarázzák azokat, a leírásokat kiegészítem saját megjegyzéseimmel, magyarázataimmal, illetve

\footnotetext{
Schram 2006.

Roche - Stuart 2015.

10 A különféle mongóliai és Mongólián kívül élő mongol népcsoportok temetési formáiról lásd Simonkay 2010. A hagyományos szokásokról lásd Sárközi 1996. A modern, 20. századi mongóliai temetésekről lásd Humphrey 2002, Delaplace 2006 és Delaplace 2008. A különféle mongol népcsoportok halálhoz kapcsolódó szokásairól lásd Qurčabilig 2003 (sajnos nem jelzi, melyik szokás mely területre jellemző). A kalmükökről lásd Birtalan - Rákos 2002: 86-87 és Birtalan 2011: 144-148, a belső-mongolok temetési szokásairól lásd Narsu - Stuart 1994, az ordoszi mongolok temetéséről lásd Kler 1936, a dahúr temetési szokásokról lásd Humphrey Urgunge 2003: 194-197.
} 
a Balogh Mátyással 2007-ben végzett terepmunkánk során a minhei Wenjia 文家 faluban gyújtött adatainkkal. ${ }^{11}$

Hasonlóan a kínai hagyományokhoz, a legtöbb mongvor családban - bár egyes családok a költségek miatt ezt nem engedhetik meg maguknak, mások pedig ijesztônek tartják ezt a szokást - az idős rokon eltávozására már jóval halála eloott felkészülnek, s elkészítik a koporsót, melyben addig, míg meg nem hal az illetô, gabonát tárolnak. Előfordul az is, hogy csak a fatáblákat vágják ki, és félreteszik ôket, majd mikor tényleg szükség van rájuk, előveszik azokat, és összeszerelik a koporsót. Akármelyik szokást is követi a család, a koporsó megépítésének időszaka mindig kötött: a holdnaptár interkaláris hónapjában, azaz a szökőhónapban készítik el, s ez alkalomból látogatók jönnek, akik gratulációjukat fejezik ki. A koporsó a mongvor szabályok szerint - melyeket sok tibeti és kínai szokás sző át - gazdagon díszített. Ha a koporsót befestik, akkor az mindig piros festékkel történik. ${ }^{12}$ Hogyha az elhunyt személy férfi, akkor a koporsó két oldalára egy-egy sárkányt festenek, ha nő, akkor főnixet - ez minden bizonnyal kínai elem a mongvor temetésben, hiszen a kínai szimbolikában a sárkány a férfit, míg a főnix a nőt jelképezi. Stuart és Jun megjegyzi, hogy olyan is előfordul, hogy nincs idő arra, hogy a főnixeket felfessék a koporsóra - egy általuk tapasztalt hasonló esetben a madarak helyett azt az írásjegyet rajzolták fel, melynek a jelentése „csendes”. ${ }^{13}$ A koporsó nagyobb végére, ahol a halott feje lesz, egy szúz fiút és egy szúz lányt festenek, akik kezükben egy-egy tányért és egy pálinkás flakont tartanak - ôk szolgálják majd az elhunytat a túlvilágon. ${ }^{14}$ Ugyanez

11 Stuart - Jun 1992, Schram 2006. A gyújtésről videofelvétel is készült, lásd Balogh - Simonkay - Wen 2007.

12 A piros nem jellemző a mongol temetési szertartások során. A kínaiaknál e szín a szerencse, boldogság és jólét szimbóluma, ezért a résztvevők nem viselhetik. Érdemes viszont megjegyezni, hogy a Han-dinasztia alatt a ,jelentős személyek" (a cikkben grandees) koporsóját vörösre festették (De Groot 1892: 315). Hasonlóan, manapság is találni Qinghai más területén is olyan eseteket, ahol piros színú selyemmel borítják a koporsót.

13 Stuart - Jun 1992: 76. A szerzők nem közlik a kínai írásjegyet, és nem magyarázzák az összefüggést a főnix és a karakter jelentése között. Ennek felderítése további kutatásokat igényel.

14 A cikkben a szerzők a következőt írják: „At the larger end of the coffin, where the head of the corpse is placed” (Stuart - Jun 1992: 75). A „larger” kifejezésből arra következtetek, hogy a koporsó nem egy szabályos téglatest alakot formál, hanem a fejrésznél szélesedik. 
a fiú és lány szintén rá van hímezve egy párnára, melyet a halott feje alá tesznek. Hogyha az illetô hamarabb meghal, minthogy kész lenne a koporsó, akkor gyorsan elkészítik azt, s mivel a halottat általában három napon belül eltemetik, ezért nincs arra idő, hogy lefessék, a koporsót nem befestik, hanem vörös papírral fedik be. Szintén kínai elem lehet a koporsó tetejére festett hét csillag, melyek Stuart és Jun szerint a Nagymedve csillagképet jelképezik. ${ }^{15}$ A csillagok belsejébe a következő kínai írásjegyeket rajzolják: $y i$ 一 'egy', meng 梦 'álom', bu 不 'nem', jian 见 'látni', tian 天 'ég', di 地 'föld', lao 老 'öreg'. Érdekesség, hogy a mongvorok szokásos éves aratóünnepén, a nadunon szintén a hét csillagot kérik a résztvevők által énekelt invokációban, hogy nyissák meg az ég kapuit, melyeken keresztül az istenségek leszállhatnak a földre, és részt vehetnek az ünnepségen. ${ }^{16}$ Vélhetôen ugyanez a funkciója a hét csillagnak a koporsón is, azaz hogy kinyissák az ég kapuit az elhunyt elótt.

Ha a halottat az ősi családi temetőbe akarják temetni, akkor a hagyományos szabályok szerint járnak el arra vonatkozóan, hogy kinek hol a helye. Ha viszont máshová kell temetni (például azért, mert az ôsi temetőben már nincs több hely), akkor a yinyang 阴阳 ${ }^{17}$ (egy Qinghaiban ismert, félig-meddig taoista vallási specialista, aki nem csak a mongvoroknál, de a helyi kínaiak között is tevékenykedik) feladata, hogy kiválassza, hová lehet temetni az elhunytat. ${ }^{18} \mathrm{~A}$ lehetséges helyek meglehetôsen korlátozottak, mert a földeket felosztották, s ráadásul még azzal is fenyegetett a kormány, hogy 1989-től

15 Stuart-Jun 1992: 75.

16 Roche 2011: 118-120. A mongvor nadun csak alakjában rokonítható a halha mongol nādammal, az ünnepség jellegét tekintve nincs közük egymáshoz. A nadunról lásd Roche 2011.

17 Schram nem ír a yinyangról, csak egy bizonyos „, master of ceremonies”-t, ,,ceremóniamestert” említ (Schram 2006: 499), ám azt gyakran kiemeli, hogy a temetési szokásokban taoista elemek fedezhetók fel.

18 Schram szerint a helyet egy láma választja ki, méghozzá botja szellemének útmutatása alapján. Ezután a láma a kiválasztott helyre egy újonnan készült nemezdarabot terít, aminek a tetejére egy 8 láb hosszú vörös pamutanyagot helyez, majd letérdel, és a csengőjét rázva és dobját verve szent szövegeket kántál. Eközben a résztvevők pénzdarabokat szórnak a szőnyegre, mellyel - úgy tartják - megvásárolják a kijelölt földdarabot. Mikor a láma végzett, föláll, és kihirdeti, hogy a hely istensége beleegyezett a vásárba, megengedi, hogy ott végezzék a hamvasztást, $\mathrm{s}$ egyúttal megígéri, hogy minden bajt elhárít a család feje fölül, mely a hamvasztás miatt érné őket. Ezután a láma négy nyilat szúr le a földbe, kijelölve ezzel a hamvasztásra szánt terület határait (Schram 2006: 499). 
betiltják a földbe temetést. ${ }^{19}$ Ennek ellenére úgy látszik, olyan fontos volt a helyieknek a temetés e módja, hogy a megmúvelendő földekből különítettek el temetőnek való területeket, sőt még a rájuk kiszabott büntetéseket is inkább kifizették, mint hogy családtagjaikat elhamvasszák. ${ }^{20}$ Vannak olyan családok is, akik eldugott, lakatlan helyeken választanak temetôt maguknak, de ez kényelmetlen, mert az évenkénti megemlékező szertartásokra így nehezebb eljutniuk. ${ }^{21}$

Ha egy új családi temetkezési helyet alapítanak, akkor egy úgynevezett bengbát (egy kis befőttesüveget) készítenek, és eltemetik azt másfél méterre a sír fölött. ${ }^{22}$ A lukba, melybe a bengba kerül, 6 követ tesznek, melyeket a Sárga-folyóból hoztak. Ebből a hat kőből egyet a bengba alá helyeznek, négyet a bengba oldalaihoz, egyet pedig a tetejére. A bengbába 24 tárgyat raknak, melyeket az alábbi kategóriákba lehet sorolni: gabonafélék (árpa, csupasz árpa, fehér bab, nagy bab, kis bab, repce, rizs, köles és fehér ricinusbab), ötszínú selyemszalag és szatén, a buddhista nyolc kincs ${ }^{23}$ továbbá négy drága gyógyszer (fekete ricinus olajnövény magvai, arora, jurora és banqua $^{24}$ ).

19 Stuart-Jun 1992: 76.

20 Schram (2006: 497) arról ír, hogy a hamvasztás szokását a buddhizmus elterjedésével vették fel a mongvorok, és bár egyes családok szerint a temetésnek e módja megtisztelőbb, mint a földbe temetés, mások mégis ez utóbbit tartják jobbnak.

21 Schram (2006: 501) szintén beszámol egy úgynevezett ősök tiszteletének az ünnepéről, melyet áprilisban tartanak; vélhetően ugyanerről a szertartásról van szó.

22 Stuart - Jun 1992: 77. Bár a szerzők nem említik, a bengba vélhetően a tibeti bum-pa 'váza', 'edény' torzított alakja.

23 A nyolc kincs, vagy más néven a nyolc szerencsés jel a következőket foglalja magában: 1 . két hal (a világuralkodó jelképe); 2. ernyő (a királyi méltóság jelképe); 3. kagyló (a győzelem jelképe); 4. lótusz (a tisztaság jelképe); 5 . zászló (a vallás győzelmének jelképe); 6. váza (nektártartó, a hosszú élet jelképe); 7. kerék (a dharma jelképe); 8. végtelen csomó (a végtelen lét jelképe). Vö. Waddell 1971: 392.

24 Stuart - Jun 1992: 77. A cikkben így szerepelnek, ám a szerzők beismerik, hogy nem tudják, miféle növényekről lehet szó. Valószínúleg így hallották kiejteni a növények nevét, de véleményem szerint ezek inkább a ru-ra és skyu-ru-ra lehetnek: az első - melyet gyakran Buddha tart a kezében a különféle ábrázolásokon - a haritaki, vagy más néven indiai cserzőgubacs (Terminalia chebula), míg a második az amla, vagy indiai pöszméte (Emblica officinalis vagy Phyllanthus emblyca). A negyedik növény, a banqua, talán inkább a bar-u-ra (Terminalia belerica) lehet. Ez abból sejthetó, hogy az a ru rát, a skyu r u rát és a ba r u rát együtt a „három gyümölcsként" szokták emlegetni, melyeket gyógyítási célokra használnak. Írott tibeti alakjaik: a-ru-ra, skyu-ru-ra, bar-u-ra. 
Mint már említettuik, ha valaki meghal, akkor a család elhívja a yinyangot, aki nemcsak a koporsó díszítésében vesz részt, hanem az egész temetési szertartást ő irányítja. Ő az, aki az elhunyt születésének és halálának pontos ideje alapján ki tudja számolni, hogy mikor kell eltemetni a halottat, illetve, ha valami oknál fogva a halottat nem az ősi temetôbe temetik el, és a temetés helye nem lett kiválasztva, akkor azt is a yinyang mondja meg, hogy hová temessék.

Hogyha a temetkezéshez a régi családi temetőt használják, akkor mihelyst meghal az illető, az emberek versenyt futnak a sírig, és az elhunyt ruháját hozzádörzsölik a földhöz, majd ezekkel a ruhákkal visszaszaladnak. E szokás értelme ismeretlen; esetleg lehet, hogy ezáltal jelzik másoknak, hogy a sírhelyet lefoglalták. Ezután ezeket a ruhákat vagy elégetik, vagy a család megtartja, vagy odaadják valakinek (legtöbbször az anyai nagybátynak, ha még életben van).

Eközben a holttestet felöltöztetik az előre elkészített temetési ruhába adatközlőnk szerint ez mindig új ruha és új cipő kell, hogy legyen -, melyet a gyermekek akkor szoktak elkészíteni, amikor szülőjük elérte a 60 éves kort. Ha valaki úgy hal meg, hogy a gyermekei nem készítették el a halotti ruhát, akkor a gyerekeket a közösség megdorgálja, amiért nem törődtek eléggé a szüleikkel, és nem tisztelték őket. A felöltöztetett holttestet az északi szoba közepén egy emelvényre helyezik, fejével az ajtó felé, lábait és bokáit pedig ricinusszálakkal összekötik, majd az egész testet letakarják egy takaróval. Ha a koporsó - melyet télen ricinusszálakkal bélelnek ki, s erre egy vattával kitömött matracot tesznek, nyáron pedig, hogy ne terjedjen a rossz szag, meszet öntenek az aljára, és ennek a tetejére teszik a matracot - elkészült (vagy pedig előre elkészítették), akkor a második napon teszik bele a holttestet, úgy, hogy karjai teljesen ki legyenek nyújtva az oldala mentén. Adatközlőnk megemlítette, hogy a halott mellé fehér virágot, füstölőt, olajos termés héját (hogy a férgek ne egyék meg a holttestet túl hamar) és mécsest tesznek, mely utóbbi azért fontos, mert a fényénél az elhunyt el tud menekülni, ha a pokolból érte jönnek. A mongvorok elmondása szerint néhányan könyvet is tesznek a halott mellé, melynek nem kell feltétlenül szent szövegnek lennie, 
csak azért kell, hogy az elhunyt a következő életében tanult emberré válhasson. Azt is szigorúan előírják, minek nem szabad lennie a koporsóban: nem szabad például nemezt, állatbőröket és fémet beletenni, csakúgy, mint - ahogy késóbb látni fogjuk - a sírba sem. Itt kell megemlítenünk még egy, ezúttal a színekre vonatkozó tabut: mongvor adatközlónk külön kiemelte, hogy a halott gyermekei fekete ruhát kell, hogy viseljenek a temetésen, mely ugyan lehet akár sötétkék is, de színes semmiképp, kiváltképp nem vörös, mivel az - szerte Kínában - az élet és a vidámság színe.

Mielôtt a koporsó fedelet feltennék, ricinusszálakat tesznek a holttestre. Ezután két férfi rányomja a fedelet a koporsóra, majd a férfirokonok (xiaozi 孝子, kínai „szülőtisztelő fiú”) kihúzzák azokat a szálakat, melyek kilógnak a fedél alól. Úgy tartják, hogy az elhunyt azt szerette a legjobban, aki a leghosszabb szálat húzta ki, és ez olyan jó ómennek számít, hogy az illető ezt a szálat később a csípője köré tekerve viseli, az elhunyt szeretete jeleként.

Délután, amikor eljön az ideje, hogy kivigyék a koporsót, megérkezik a yinyang. De még valamivel ezelőtt (a pontos idôpont nincs meghatározva) 20 és 50 közti számú siratóasszony (manie ${ }^{25}$ ) leül az előkészített szalmára az udvar déli részébe. Ha az udvar közepén egy fa áll, akkor néhányan az asszonyok közül felkötnek rá egy qianliangot 銭糧 és egy baogait 宝蓋 (ezek papírból kivágott alakzatok, ruhát, pénzt vagy lovat szimbolizálnak, melyeket elégetnek, s ezáltal áldozatként eljuttatják óket az istenekhez), és énekelve körbejárják a fát. A szobában a lámák a fekhelyen ülve szintén folyamatosan kántálnak. A szénával borított padlón a férfirokonok és női rokonok összegyúlnek, és siratják az elhunytat. A mongvoroknak van egy szólásuk, amelyben a 80 év feletti elhunytat egy túlérett gyümölcshöz hasonlítják, mely lepottyan a fáról - ezzel azt fejezik ki, hogy az öregek átadják helyüket a fiataloknak.

Amikor a feketébe öltözött, yin 阴 és yang 阳 díszítéssel ellátott sapkát viselő yinyang megérkezik, egy-egy piros szalagot, mahongot adnak át neki. Ezeket a két vállán átveti és a mellén keresztezve megköti, majd a koporsó

25 A manie valószínőleg a halha mongol mān' (írott mongol māni) ,ima, ráolvasás” szóval rokonítható. 
felé nézve a jobb kezével és a jobb térdével megérinti a földet, majd szembefordul az udvarban várakozó gyászolókkal, és megismétli ugyanezt a mozdulatot. Ezután egy embert behív a szobába a koporsó mellé, és kezébe ad egy öt különböző színú szálból sodort kötelet, míg egy másik, udvaron álló ember pedig a kötél másik végét kell, hogy tartsa, úgy, hogy a kötél szobában lévő vége a koporsó fejrésze fölött haladjon el. Ezután a yinyang a xiaozik bal kezének középső ujját megszúrja, miközben azok azt kiáltják: „Apa!” vagy „Anya!” - az elhunytra hivatkozva. A kis sebekből kibuggyanó vért a yinyang összegyújti, és belemártva előzőleg még tintába is merített ecsetjét, írni kezd a koporsóra: 11 vagy 13 írásjegyet (páros számúakat nem szabad írni) rajzol fel egy hosszú, keskeny fehér részre a lány és a fiú ábrája közé. Ezek az írásjegyek változó, hogy mik lehetnek, pl. bing 病 'betegség', lao 老 'öregség', sheng 生 'élet', $s i$ 死 'halál', $k u$ 苦 'keserúség', az elhunyt neve (három írásjegy), ling 灵 'szent', wei 位 'hely', vagy a zhi 之 karakter, mely birtokviszonyt fejez ki. Mikor végzett, a válla fölött elhajítja az ecsetet, a közelben állók pedig igyekeznek azt elkapni, mivel úgy tartják, hogy annak a gyermeke, aki elkapja, nagy tudóssá válik.

Mindeközben egy asszony és számos kíséró elindul a sírhely felé, s útközben jajgatva temetési kenyeret és papírt (bár Stuart és Jun nem egyértelmúsíti, de valószínúleg szellempénzrốl van szó) szórnak szét. Nem sokkal utánuk néhány fiatal férfi is elindul; kezükben azok a papírfüzérek, melyek korábban még az udvart és a ház plafonját díszítették. Ezután - a yinyang által megjelölt időpontban - kiviszik a koporsót a szobából, gondosan ügyelve, hogy az ajtókeretet ne érintsék, mivel az szerencsétlenséget okozhatna. ${ }^{26}$ Ezt elkerülendő a yinyang, mihelyst kivitték a koporsót, egy varázsigét ragaszt a szemöldökfára, ezzel is megakadályozva, hogy a halott lelke gonosz szellem alakjában visszatérjen. Hasonló varázsigéket ragasztanak még a halottas

26 Az ajtó, a keret, és különösen a szemöldökfa nem csak a mongvoroknál, hanem általában a mongolok körében - csakúgy, mint sok más népnél - tabu, mivel nemcsak az otthont és a külvilágot választja el egymástól, hanem egyfajta átjárót is képez az emberi és a szellemi világok között. Érdemes viszont megjegyezni, hogy a születés és halál idején gyakran jelentkezik a „fordított világ” elképzelés, aminek során mindent éppen a hétköznapokhoz képest ellentétesen végeznek, azaz ilyenkor ráállnak a küszöbre, belekapaszkodnak az ajtó szemöldökfájába stb., lásd Birtalan Ágnes (1996: 20) megfigyeléseit a nyugat-mongóliai zahcsinoknál. 
szoba falaira, illetve az udvar kapujára. Ugyanezt a célt - az ártó szellemek távoltartását - szolgálják az udvaron meggyújtott petárdák. ${ }^{27}$

Miután a koporsót kivitték, két székre állítják, és az oldalaihoz két póznát kötnek, hogy ezeket fogva tudják majd később a sírhelyre vinni. A fedélre egy kakast kötnek, melyről azt gondolják, hogy mindenféle ártó szellemet távol tart, s így nem csak az egész temetési menetet védi meg, hanem magát az elhunytat is. ${ }^{28}$ Még mieloott a menet elindulna, a yinyang figyelmezteti az olyan évek szülötteit, melyek szerencsétlenséget hozhatnak. Aki ilyen állat évében született, annak nem szabad a koporsót vinnie, illetve szigorúan a koporsó mögött kell haladnia, sosem előtte. Miután elrendeződött a menet, elindulnak a temetés helyszíne felé. A koporsót vivő férfiak igyekeznek minél gyorsabban haladni - sôt idônként még szaladni is -, ugyanis a néphit szerint annál boldogabb lesz az elhunyt, minél hamarabb ér végső nyughelyére.

A kijelölt helyre érve az óra járásával ellenkező irányban a koporsóval háromszor megkerülik a sírt, mely általában egy körülbelül két méter mély nagy gödörből és egy ehhez csatlakozó oldalsó vájatból áll - ez utóbbiba kerül majd a koporsó. Az elhunyt legidősebb fia leszáll a sírba, és ellenőrzi, nehogy bármilyen fémdarab legyen benne, ugyanis ez feldühítené az elhunyt szellemét, és betegséget, szerencsétlenséget hozhatna a családra. Ha a fiú mindent rendben talált, a kötelekkel leeresztik a koporsót a sírba, és gyorsan az oldalsó üregbe helyezik. A koporsó fejénél lévő kis párkányra egy lisztből készült lámpást helyeznek, valamint kis botokat és köveket, melyekre démonűző varázsigéket írtak. ${ }^{29}$

A yinyang egy ötszínú zsinórral és egy iránytúvel, melyre a 10 égi törzset (az öt elem férfi és női nemben: jia 甲, $y i$ 乙, bing 丙, ding 丁, $w u$ 戊, $j i$ 己,

27 A petárdákkal való szellemúzés egész Kína-szerte elterjedt szokás, nem csupán a mongvorokra jellemző.

28 A kakas megjelenése a temetéseken (vagy a koporsó fedelére kötve, vagy a sír felett átdobva) szintén egész Kína-szerte elterjedt, sôt még Malajziában és Szingapúrban is eloofordul, ezért kijelenthetjük, hogy ez nem egy tipikus mongvor, hanem inkább délkelet-ázsiai szokás, melynek hátterében általában az a hiedelem áll, mely szerint a kakas (mivel hajnalban kukorékol, amikor a szellemek visszavonulnak) távol tartja a gonosz szellemeket, ártó démonokat. Errool és a kakassal kapcsolatos egyéb kínai babonákról lásd Williams 1974: 207.

29 A lámpás itt szintén azt a célt szolgálhatja, hogy az elhunyt lelkének világítson útja során a szellemvilágban. 
geng 庚, xin 辛, ren 壬, gui 癸) és a 12 földi ágat ( $z i$ 子, chou 纽, yin 寅, mao 卯, chen 辰, si 巳, $w u$ 午, wei 未, shen 申, you 西, $x u$ 戌 és hai 亥) írták, kiszámítja a koporsó pontos elhelyezését, majd még több, varázsigével ellátott botot és követ szórnak a sírba. ${ }^{30}$ Olyannyira fontos a gondos elhelyezés, hogy a halott fia még a koporsót is felnyitja, hogy megnézze, nem mozdult-e el a holttest, majd meggyújtja a párkányon lévő lámpást. Ezután az üreget vályogtéglákkal vagy földdel lezárják. A yinyang a temetési kenyérből darabokat szór a sírba, majd meggyújtja a papírfüzéreket, s míg azok égnek, alkoholt locsol a földre - ezzel a szellemeknek áldoz -, és kántálni kezd. Ezután a legidősebb fiú a koporsónak háttal letérdel, s a válla fölött egy lapáttal földet szór a sírba, jelezve, hogy ezzel véget értek a kötelezettségei az idősebb és a fiatalabb generációval, illetve a Tiangerével és a Földdel szemben. ${ }^{31} \mathrm{Az}$ összegyúlt rokonok és ismerősök eközben szintén a sír előtt térdelnek, koruk, illetve az elhunyttal való rokonsági kapcsolatuk szerint elrendeződve. Miután a fiú a harmadik lapát földet is a sírba szórta, a fiatal férfiak elkezdik betemetni a sírt - ehhez fából készült ekéket használnak, melyekről szintén úgy tartják, hogy távol tartják a gonoszt. Ezután már hagyományos lapáttal is be lehet fejezni a sír betemetését, ám mielőtt ezzel teljesen végeznének, a yinyang még egy pár varázsigével ellátott botot és követ dob a sírba, ${ }^{32}$ aztán pedig a földhányást az óra járásával ellenkező irányban megkerüli, és kántálva újra alkoholt locsol szét a kupac körül.

Mikor a sírt elkezdik feltölteni, a nók és azok a férfiak, akik nem tartoznak a xiaozik körébe, elindulnak haza. A kakast is hazaviszik, s később vagy a yinyangnak adják, vagy egyszerúen visszaeresztik a tyúkok közé. Eközben az otthon maradt családtagok kitakarítják a házat, s az udvaron összegyújtik a maradék kenyeret és a füzéreket, majd egy nagy halomba rakva elégetik őket. Mikor a temetésről a többi rokon hazaér, egy lavór vízzel várják őket az udvaron, amelyben kezet moshatnak, s a házba belépve egyfajta halotti torra hívják őket, melynek folyamán a vendégek viccelődnek, nevetgélnek,

30 A 10 égi törzsról és a 12 földi ágról lásd Wilkinson 2000: 175-178.

31 A Tiangere minden bizonnyal a tengri, mely az eget, a mennyországot, valamint a fó istenséget jelöli. Az eget a mongol népek „Örök (Kék) Ég”-ként tisztelik.

32 A varázsigék pontos tartalmáról sajnos nincsen információnk. 
elfogyasztják az elkészített ételeket és - az elhunyt fiai és sógorai kivételével - alkoholt isznak. Az ünnepség végeztével, miután szétosztották a maradék kenyeret, ki-ki hazatér, ám nem ez az utolsó momentuma a végső tisztelet megadásának. Adatközlőnk szerint a temetés után hét nappal ráolvasást végeztetnek hét alkalommal, egészen a 49. napig. ${ }^{33}$ Ekkor a hozzátartozók papírt (valószínúleg ebben az esetben is szellempénzt) és kenyeret is égetnek áldozatképpen. A temetés után a rokonok különféle tabukat kell, hogy betartsanak: az elhunyt fia például nem vágathat hajat és szakállat 100 napig. A gyász egész idószaka 1 évig tart, mely idő alatt nem szabad vendégségbe menni.

\section{A „nem természetes” módon elhunytak temetése}

Mint már említettük, a fent leírtak akkor érvényesek, ha az elhunyt természetes halállal halt meg, azaz öregkorában, úgy, hogy születtek gyermekei. Az alábbiakban röviden kiemelek egy-két ettól eltéró esetet is. Azok, akik nem természetes halállal halnak meg - és ide sorolandó az is, aki nem házasodott meg, illetve nem születtek gyermekei - nem részesülnek ugyanilyen végtisztességben. A meghalt gyermekeket például egy távoli helyen egyszerúen kiteszik, s megvárják, hogy a holttestet a vadállatok megegyék - ez a szokás megegyezik a többi mongol nép gyakorlatával, azzal a különbséggel, hogy a mongvoroknál nem egy láma, hanem a yinyang mondja meg, milyen irányban induljanak el a testtel. Ha a vadállatok mégsem ennék meg a tetemet, akkor a testet egy másik helyre viszik, és szalmából tüzet gyújtanak, ami a madarakat odavonzza. A legtöbb területen azonban egyre kevesebb olyan madárfaj található már meg, mely alkalmas lenne ilyen feladatra, úgyhogy a holttestet gyakran inkább a Sárga-folyóba dobják.

Ugyanígy, különösebb szertartás nélkül, a Jangcéba dobják a várandós asszonyok koporsóba helyezett holttestét is, s azokat a fiatal férfiakat és nőket, akik még azelőtt haltak meg, hogy megházasodtak volna. Néhány helyen

33 A 49 nap bizonyára nem véletlen: a buddhizmus úgy tartja ugyanis, hogy ennyi ideig marad a halott lelke a bardóban, a köztes lét világában, mely se nem az élóké, se nem a halottaké. 
azonban az ô testüket egy vízszintes helyen vagy egy töltésbe vájt üregben elégetik. Míg az előző esetben koporsót is készítenek, melyet a hamvasztás előtt darabokra törnek, ez utóbbinál nem készítenek koporsót, csak magát a testet helyezik el egy szalmával megtöltött üregben, és mihelyst a szalma meggyullad, az üreget földdel lezárják, majd a tetején egy kis lyukat ásnak, amin keresztül a füst el tud távozni.

Más nem természetes halálok esetén (fulladás, baleset stb.) a testet szintén elégetik. Hogyha az elhunytnak voltak gyermekei, akkor a csontokat eltemetik, de sosem az ősi sírhelyen. Ha gyermektelen volt, akkor a csontokat egyszerúen szétszórják.

Azokat az asszonyokat, akik szülés közben, vetélés következtében vagy valamilyen seb miatt (például operáció alatt) halnak meg, nem szabad eltemetni, fóként nem az ôsi sírhelyen - őket általában szintén elhamvasztják. Ellenkező esetben a szellemük ártást hozna a családra, vagy esetleg az egész falura.

Míg a természetes halállal meghalt emberek esetében szinte minden esetben meghívnak a temetésre egy-két lámát, hogy imádkozzanak, a nem természetes halálok alkalmával ez nem feltétlenül történik így. Szintén nem elengedhetetlen a yinyang jelenléte: lámatemetéseken például nem vesz részt, illetve az is előfordulhat, hogy a faluban vagy a közelben nem lakik yinyang . Ilyenkor általában egy másik vallási specialistát, a falát ${ }^{34}$ hívják (ám ha van yinyang a közelben, akkor szinte minden esetben ő irányítja a temetést, nem a fala), aki, hasonlóan a yinyanghoz, szintén meg tudja mondani, hol kell a holttestet eltemetni, illetve el tudja látni az elóbbi feladatait - csak egy a különbség: a fala a szertartást transzállapotban végzi.

Fontos még megemlíteni, hogy előfordulhat, hogy a temetés után a fala és/vagy egy másik vallási specialista, a nianjiangui ${ }^{35}$ megállapítja, hogy a sírban gonosz szellem lakozik, aki a családra szerencsétlenséget hoz. Ilyenkor egy ember, akinek az arca korommal feketére van festve, kiássa a sírt, kiveszi a koporsót és abból a testet, melyet a sír mellett elégetnek.

34 A faláról részletesen lásd Stuart - Jun 1991.

35 A kínai yan jian gui 眼见鬼 kifejezésből. Szó szerint ,,a szeme ördögöt lát” - általában egy han nő, aki látja a démonokat. 


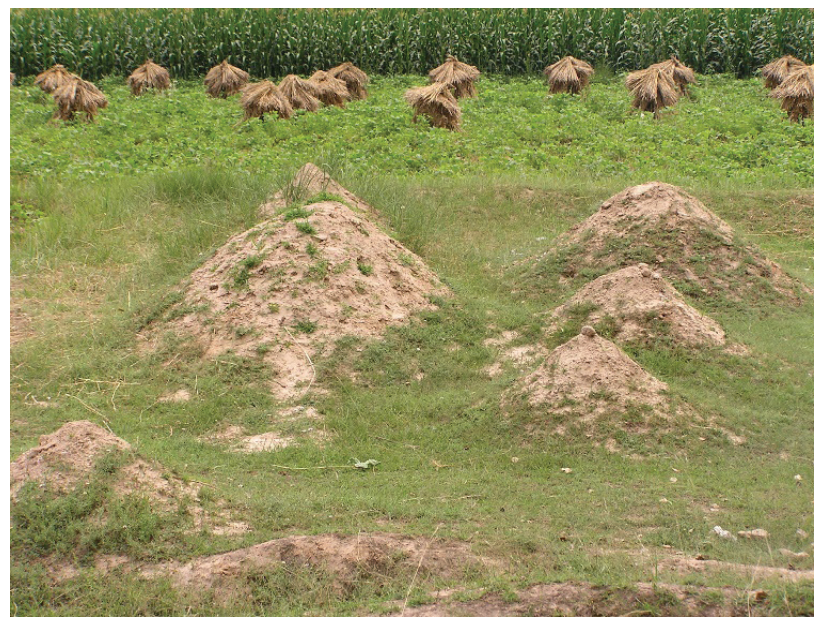

1. ábra: Mongvor családi sírhely.

A nagyobb sírokban a szülők, míg a kisebbekben a gyermekek nyugszanak. (Saját fotó, Wenjia, Minhe, Hui és Mongvor autonóm megye, Qinghai, Kína, 2007.)

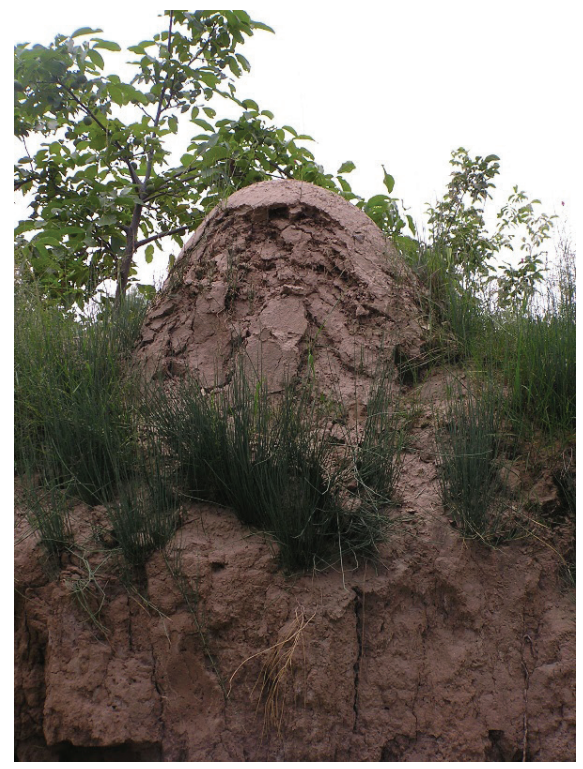

2. ábra: Mongvor láma sírja.

(Saját fotó, Wenjia, Minhe, Hui és Mongvor autonóm megye, Qinghai, Kína, 2007.) 


\section{Hivatkozott szakirodalom}

Balogh, Mátyás - Simonkay, Zsuzsanna - Wen, Xiang Cheng 2007. Minhe Monguor Customs: Interview with Wen De Liang. Wenjia; Minhe; Qinghai; China 2007. In: Balogh Mátyás (szerk.) Belsô-Ázsia Archívum No. 21v. (videófelvétel).

Birtalan Ágnes 1996. „Zahcsin viselkedési tabuk.” In: Birtalan Ágnes (szerk.) Őseink nyomán Belsó-Ázsiában: Tanulmányok a mongol népi hiedelemvilágról I. Budapest: Nemzeti Tankönyvkiadó, 28-46.

Birtalan, Ágnes (ed.) 2011. Kalmyk Folklore and Folk Culture in the mid-1 $9^{\text {th }}$ Century: Philological Studies on the Basis of Gábor Bálint of Szentkatolna's Kalmyk Texts. [Oriental Studies 15.] Budapest: Library of the Hungarian Academy of Sciences - Elista: Kalmyk Institute of Humanitarian Studies of the Russian Academy of Sciences.

Birtalan Á. - Rákos A. 2002. Kalmükök. Egy európai mongol nép. Budapest: Terebess.

De Groot, J. J. M. 1892. The Religious System of China. Vol. 1. Book 1. Disposal of the Dead. Leyden: Brill.

De Smedt, A. - Mostaert, A. 1929-1931. „Le dialecte monguor parlé par les Mongols du Kansou occidental, $1^{\mathrm{e}}$ partie: Phonétique." Anthropos 24: 145-166, 801-815; 25: 657-669, 961-973; 26: 253.

De Smedt, A. - Mostaert, A. 1933. Le dialecte monguor parlé par les Mongols du Kansou occidental, $3^{e}$ partie: Dictionnaire monguor-français. [Publications de l'Université Catholique de Pékin] Pei-p'ing: Imprimerie de l'Université Catholique.

De Smedt, A. - Mostaert, A. 1945. Le dialecte monguor parlé par les Mongols du Kansou occidental, $2^{e}$ partie: Grammaire. [Monumenta Serica Monograph Series 6.] Peking: The Catholic University. 
Delaplace, Grégory 2006. „The Place of the Dead: Power, Subjectivity and Funerary Topography in North-Western Mongolia." In: David Sneath (ed.) States of Mind: Power, Places and the Subject in Inner Asia. Bellingham: Western Washington University Press, 47-62. $<$ http://www.gregorydelaplace.com/images/docs/ delaplaceplacedead.pdf> [letöltve: 2010-08-20].

Delaplace, Grégory 2006. L'invention des morts: Sépultures, fantômes et photographieen Mongolie contemporaine. Paris: CEMPS-EPHE.

Humphrey, Caroline 2002. „Rituals of Death as a Context for Understanding Personal Property in Socialist Mongolia." The Journal of the Royal Anthropological Institute 8.1: 65-87.

Humphrey, C. - Urgunge, Onon 2003. Shamans and Elders: Experience, Knowledge, and Power among the Daur Mongols. Oxford: Clarendon Press.

Kara György 1985. „Etyma monguorica.” Acta Orientalia Hung. 39.1: 3-23.

Kler, Joseph 1936. „Sickness, Death, and Burial among the Mongols of the Ordos Desert." Primitive Man 9.2: 27-31.

Mostaert, Antoine 1931. „The Mongols of Kansu and their Language.” Bulletin of the Catholic University of Peking 8: 75-89.

Narsu - Stuart, Kevin 1994. „Funerals in Alxa Right Banner, Inner Mongolia.” Mongolian Studies: Journal of the Mongolia Society 17: 99-103.

Potanin, G. N. 1893. Tangutszko-Tibetszkaja okraïna Kitaja i Central'naja Mongolija. Szt. Peterszburg.

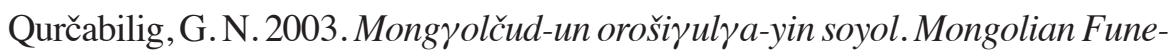

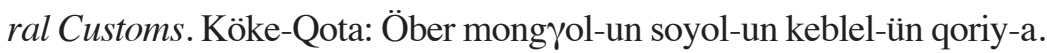

Roche, Gerald 2011. Nadun: Ritual and the Dynamics of Cultural Diversity in Northwest China's Hehuang Region. (PhD diss., Griffith University) 
Roche, Gerald - Lcag Mo Tshe Ring 2013. „Notes on the Maintenance of Diversity in Amdo: Language Use in Gnyan Thog Village Annual Rituals." Studia Orientalia Electronica 113: 165-180.

Roche, Gerald - Stuart, KC 2015. „Introduction: Mapping the Mongour.” Asian Highlands Perspectives 36: Mapping the Mongour 5-15.

Roche, Gerald - Stuart, KC (eds.) 2015. Mapping the Mongour. Asian Highlands Perspectives 36. (Online kiadás: http://himalaya.socanth.cam. ac.uk/collections/journals/ahp/pdf/AHP_36.pdf)

Róna-Tas András 1966. Tibeto-Mongolica: The Tibetan Loanwords of Monguor and the Development of the Archaic Tibetan Dialects. [Indo-Iranian Monographs 7.] Budapest: Akadémiai Kiadó; The Hague: Mouton.

Róna-Tas András 2014. Tibeto-Mongolica Revisited: With a New Introduction and Selected Papers on Tibetan Linguistics. Leiden: Brill.

Schram, Louis MJ 1932. Le mariage chez les T'ou-jen du Kan-sou. [Variétés Sinologiques 58.] Chang-hai: Imprimerie de la mission catholique.

Schram, Louis MJ 1954a. The Monguors of the Kansu-Tibetan Frontier: Their Origin, History, and Social Organization. [Transactions of the American Philosophical Society 44:1.] Philadelphia: American Philosophical Society.

Schram, Louis MJ 1954b. The Monguors of the Kansu-Tibetan Frontier, Part II.: Their Religious Life. [Transactions of the American Philosophical Society 47:1] Philadelphia: American Philosophical Society.

Schram, Louis MJ 1961. The Monguors of the Kansu-Tibetan Frontier, Part III.: Records of the Monguor Clans. [Transactions of the American Philosophical Society 51:3.] American Philosophical Society.

Schram, Louis MJ 2006. The Monguors of the Kansu-Tibetan Frontier. Ed. Kevin Stuart. Introd. Juha Janhunen, Paul Nietupski, Gray Tuttle, Keith Slater, Jeroom Heyndrickx, Limusishiden and Kevin Stuart. Xining City: Plateau Publications. 
Schröder, Dominik 1952-1953. „Zur Religion der Tujen des Sininggebietes (Kukunor)." Anthropos 47: 1-79, 620-658, 822-870; 48: 202-249.

Schröder, Dominik 1959. Aus der Volksdicntung der Monguor, 1. Teil: Das weisse Glücksschaf (Mythen, Märchen, Lieder). [Asiatische Forschungen 6.] Wiesbaden: Harrassowitz.

Schröder, Dominik 1964. „Der Dialekt der Monguor.” In: B. Spuler (ed.) Mongolistik [Handbuch der Orientalistik, 1. Abteilung, 5. Band, 2. Abschnitt]. Leiden: Brill, 143-158.

Schröder, Dominik 1970. Aus der Volksdichtung der Monguor, 2. Teil: In den Tagen der Urzeit (Ein Mythus vom Licht und vom Leben) [Asiatische Forschungen 6.] Wiesbaden: Harrassowitz.

Simonkay Zsuzsanna 2010. Halállal, temetéssel kapcsolatos szokások, hiedelmek a mongoloknál. (MA szakdolgozat, Budapest ELTE, Belső-ázsiai Tanszék).

Stuart, Kevin - Jun, Hu 1991. „The Tu Fala: Trance Mediums of Northwest China." Shaman's Drum 23: 28-35.

Stuart, Kevin - Jun, Hu 1992. „Death and Funerals among the Minhe Tu (Monguor)." Asian Folklore Studies 51: 67-87.

Todaeva, Buljas Hojcsievna 1973. Mongorszkij jazük: Isszledovanie, teksztü, szlovar. Moszkva: Insztitut Vosztokovedenija AN SZZSZR.

Waddell, L.A. 1971. The Buddhism of Tibet or Lamaism. Cambridge: Heffer.

Wilkinson, Endymion 2000. Chinese History: A Manual. Cambridge (Mass.) - London: Harvard University, Asia Center.

Williams, C. A. S. 1974. Chinese Symbolism and Art Motifs: A Comprehensive Handbook on Symbolism in Chinese Art through the Ages. Tokyo: Tuttle. 